\title{
Differential effects of an erythropoietin receptor gene disruption on primitive and definitive erythropoiesis
}

\author{
Chyuan-Sheng Lin, ${ }^{1}$ Sai-Kiang Lim, ${ }^{1}$ Vivette D'Agati, ${ }^{2}$ and Frank Costantini ${ }^{1,3}$ \\ ${ }^{1}$ Department of Genetics and Development and ${ }^{2}$ Department of Pathology, College of Physicians \& Surgeons, Columbia \\ University, New York, NY 10032 USA
}

\begin{abstract}
Although the hormone erythropoietin (Epo) and its receptor (EpoR) are known to play important roles in the regulation of erythropoiesis, several questions remain concerning the developmental role of Epo/EpoR signaling. As the functions of Epo have been defined primarily through studies of definitive erythroid cells, its importance for primitive, embryonic erythropoiesis remains uncertain, as does the significance of EpoR expression in several nonerythroid cell types. To address these questions, mouse embryonic stem cells and embryos lacking a functional EpoR gene were produced by gene targeting. The effects of the mutation were examined in embryos developing in vivo, in chimeric adult mice produced with homozygous mutant embryonic stem cells, and in hemopoietic cells cultured in vitro. No defects were apparent in nonerythroid cell lineages in which the EpoR normally is expressed, including megakaryocytes and endothelial cells. In the mutant yolk sac, primitive erythrocytes were produced in normal numbers, they underwent terminal differentiation, and expressed near normal levels of embryonic globins, although they were reduced in size and their proliferation was severely retarded after E9.5. In contrast, in the fetal liver, definitive erythropoiesis beyond the late progenitor (CFU-E) stage was drastically inhibited by the EpoR mutation, and virtually no definitive erythrocytes were produced in vivo, leading to embryonic death by E13.5. Thus, our results suggest a fundamental difference in the molecular mechanisms stimulating primitive and definitive erythropoiesis. It was also observed that a few mutant definitive erythroid cells could terminally differentiate when cultured with additional cytokines, demonstrating that although Epo/EpoR signaling is important for definitive erythroid cell survival and proliferation, it is not an obligatory step in differentiation.
\end{abstract}

[Key Words: Erythropoietin receptor; gene disruption; erythropoiesis; signaling; proliferation; differentiation]

Received September 12, 1995; revised version accepted November 15, 1995.

The glycoprotein hormone erythropoietin (Epo), which is produced primarily in the adult kidney, is the major regulator of red blood cell production in adult mammals (Krantz 1991). Epo acts by binding to its cognate receptor (EpoR) (D'Andrea et al. 1989), which is a member of the cytokine receptor superfamily (Bazan 1990), and is expressed on the surface of erythroid progenitor cells. Signaling through the EpoR leads to rescue from apoptosis, cell proliferation, expression of erythroid specific proteins such as hemoglobins, and ultimately to terminal differentiation into mature, enucleated erythrocytes (Barber and D'Andrea 1992; Ihle et al. 1993; Youssoufian et al. 1993).

Despite a wealth of information on the role of Epo and EpoR in adult erythropoiesis and the mechanisms of EpoR signaling, a number of questions remain concerning the role of the EpoR during mammalian development. In mammals, the earliest erythroid cells arise in the blood islands of the yolk sac [beginning at approxi-

${ }^{3}$ Corresponding author. mately embryonic day 8.0 (E8.0) in the mouse], and these give rise to the primitive, or embryonic, lineage of red blood cells (Moore and Metcalf 1970; Russell 1979). Primitive erythrocytes differ from definitive, or adult, erythrocytes in that they retain their nucleus throughout their differentiation, and express a distinct set of "embryonic" hemoglobins (Craig and Russell 1964). Definitive erythroid cells, which express adult hemoglobins and undergo enucleation before release into the circulation, are produced first in the fetal liver, and after birth in the bone marrow and (in mice) the spleen (Russell 1979). Whether the definitive erythroid lineage is seeded by hemopoietic stem cells from the yolk sac, or arises de novo in other intraembryonic sites, remains a subject of debate (Moore and Metcalf 1970; Wong et al. 1982; Godin et al. 1993, 1995; Medvinsky et al. 1993). As the functions of Epo have been defined primarily through studies of definitive erythroid cells, or cell lines derived from definitive erythroid cells, its importance for primitive erythropoiesis remains uncertain. Some studies have suggested that yolk sac erythropoiesis occurs indepen- 
dently of Epo (Cole and Paul 1966; Ripoche and Cudennec 1983; Labastie et al. 1984), whereas other studies have shown that primitive erythrocytes express the EpoR and respond to Epo stimulation (Bateman and Cole 1971; Boussios et al. 1989; Keller et al. 1993).

In the definitive erythroid lineage, the most Epo-sensitive target cell is the colony-forming unit-erythroid (CFU-E), a relatively late erythroid-committed progenitor cell, which in the presence of Epo, divides several times before undergoing terminal differentiation land thus gives rise to colonies of 8-64 red cells when cultured in vitro for 2 days). Earlier erythroid progenitors also respond to Epo, and most evidence suggests that Epo sensitivity arises at a stage somewhere between the burst forming unit-erythroid (BFU-E; the earliest committed erythroid progenitor) and the CFU-E (Gregory 1976; Iscove 1977). However, the EpoR is also expressed by some multipotential hemopoietic cell lines and stem cell lines (Migliaccio et al. 1991; Schmitt et al. 1991; Heberlein et al. 1992), and whether it may play a role in vivo at an early stage of hemopoiesis is unclear. Finally, several nonerythroid cell types, including megakaryocytes (Ishibashi et al. 1987; Fraser et al. 1989), fetal liver stromal cells (Ohneda et al. 1993), endothelial cells (Anagnostou et al. 1990, 1994), and neural cells (Masuda et al. 1993; Liu et al. 1994), express the EpoR and respond to Epo stimulation, although its developmental or physiological functions in these cell types have not been well defined.

To examine directly the importance of the EpoR for primitive and definitive erythropoiesis, as well as its role in other cell types in the developing embryo, we produced mouse embryonic stem (ES) cells in which the EpoR gene was disrupted by homologous recombination. Hemopoiesis was examined during the in vivo development of homozygous mutant embryos and in cultures of mutant hemopoietic cells in vitro. In addition, homozygous mutant ES cells were derived, and their ability to contribute to blood cell lineages in adult chimeric mice was tested.

\section{Results}

\section{Targeted disruption of the EpoR gene}

To ensure production of a nonfunctional allele of the EpoR gene, a targeting vector was designed to induce a deletion of six of the eight exons of the gene upon integration into the EpoR locus by homologous recombination (Fig. 1a). The deleted exons encode most of the extracellular domain of the receptor, the transmembrane domain, and a membrane-proximal cytoplasmic region required for signal transduction (Barber and D'Andrea 1992; Ihle et al. 1993; Youssoufian et al. 1993). The targeting vector was introduced into ES cells, and 11 homologous recombinant clones were identified by Southern analysis (Fig. $\mathrm{lb}$ ). The structure of the targeted allele, including the introduced deletion, was confirmed by Southern analysis using several probes and restriction enzymes (data not shown). To produce EpoR mutant

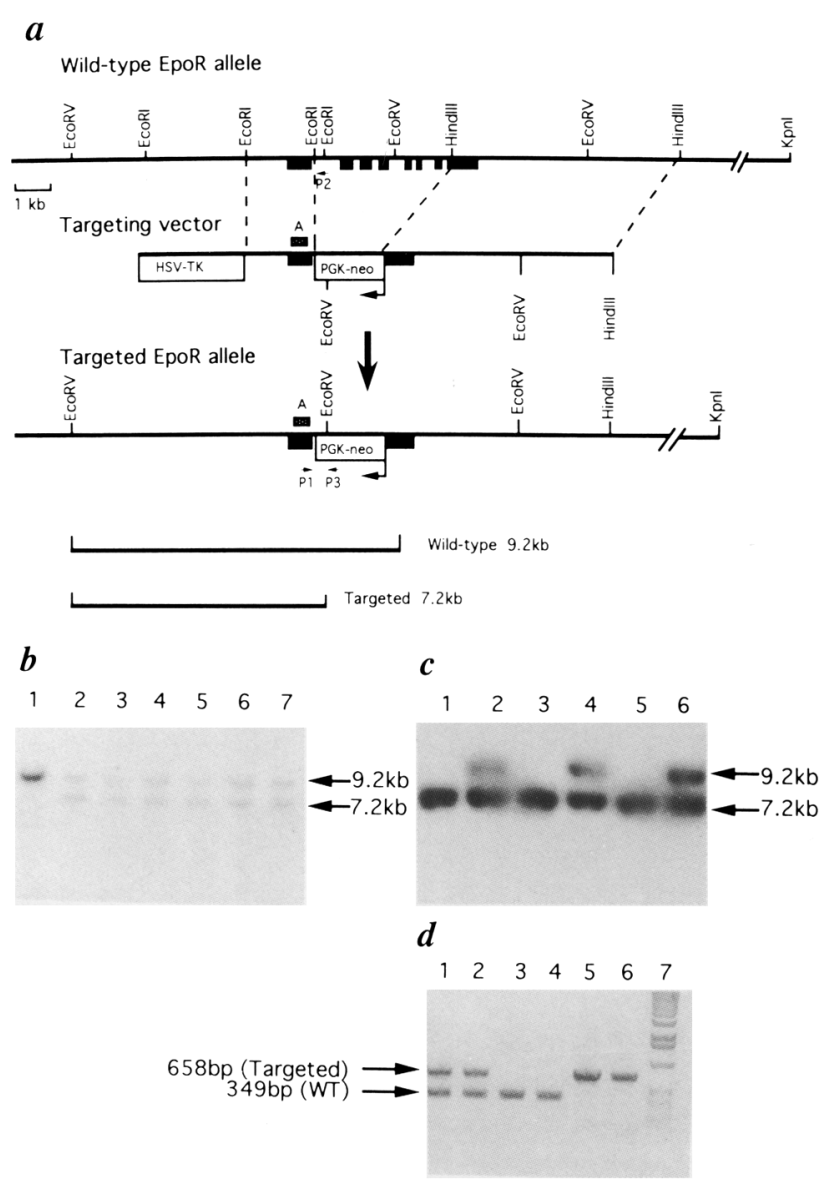

Figure 1. Targeted disruption of the murine EpoR gene. (a) Targeting strategy. Solid boxes denote exons 1-8. Exons 2-7, which are deleted in the targeted allele, encode amino acids 39-304 of the 507-amino-acid protein (Youssoufian et al. 1990). The phospoglycerokinase-neomycin (PGK-neo) gene is in reverse orientation with respect to the EpoR gene. (Bottom) Bars show the 9.2- and 7.2-kb EcoRV fragments from the wild-type and targeted alleles, detected with probe $\mathrm{A}$ (crosshatched box). Arrows labeled P1, P2, and P3 indicate PCR primers used to detect the wild-type or targeted allele. $(b)$ Southern blot analysis of wild-type ES cells (lane 1), and six EpoR +/ - clones containing one wild-type and one targeted allele (lanes 2-7). (c) Southern blot analysis of six ES cell clones surviving selection with an increased G418 concentration. Lanes 1,3 , and 5 contain homozygous mutant clones, whereas lanes 2, 4, and 6 contain heterozygous mutant clones. (d) PCR analysis of six embryos (lanes 1-6) from an intercross between EpoR $+/$ - parents. The 658-bp band, the product of primers $\mathrm{P} 1$ and P3, represents the targeted allele; the 349 -bp band, the product of primers P1 and $\mathrm{P} 2$, represents the wild-type allele. (Lane 7) Molecular mass markers $(\mathrm{kb})$.

mice, the heterozygous mutant ES cells were injected into wild-type blastocysts, and chimeric male mice were bred to transmit the mutation through the germ line. Heterozygous mutant mice had normal hematocrits, indicating that one copy of the EpoR gene is sufficient to support a normal steady-state level of red blood cells in the adult mouse. In addition, homozygous mutant ES 
cells were generated by selection of heterozygous cells (EpoR + /-) with an increased concentration of G418 (Mortensen et al. 1992), and identification by Southern analysis of surviving clones that had converted to EpoR - / - (Fig. 1c).

\section{Development of the primitive erythroid lineage in EpoR - / - embryos}

Homozygous mutant (EpoR $-/-1$ embryos, which were identified by PCR (Fig. 1d) or Southern analysis (not shown), developed normally through E9.5, the first day on which primitive blood cells can be seen circulating in the embryo and yolk sac. EpoR - / - E9.5 embryos did not appear anemic (Fig. 2A), and the number of primitive blood cells per embryo was within the normal range at this stage (Table 1). Histological sections also revealed similar numbers of primitive erythrocytes in the mutant and wild-type E9.5 yolk sac (Fig. 2B,C). Between E10.5 and E12.5, however, the embryos became increasingly anemic (Fig. 2D,G), and they died by E13.5. Primitive blood cell numbers fell to $14 \%$ of normal by E10.5 and $10 \%$ by $\mathrm{E} 12.5$, indicating that their proliferation after E9.5 was severely impeded. Thus, the formation of primitive erythrocytes in the early yolk sac and their release into the circulation appear to occur normally in the absence of the EpoR. However, at later embryonic stages these cells do become dependent on Epo/EpoR signaling to stimulate normal rates of proliferation.

The EpoR mutation had little apparent effect on the in vivo differentiation of the primitive erythroid cells. After their release from the yolk sac at $\sim \mathrm{E} 8.0-\mathrm{E} 8.5$, primitive erythrocytes continue to mature synchronously in the circulation, a process characterized by hemoglobin accu-
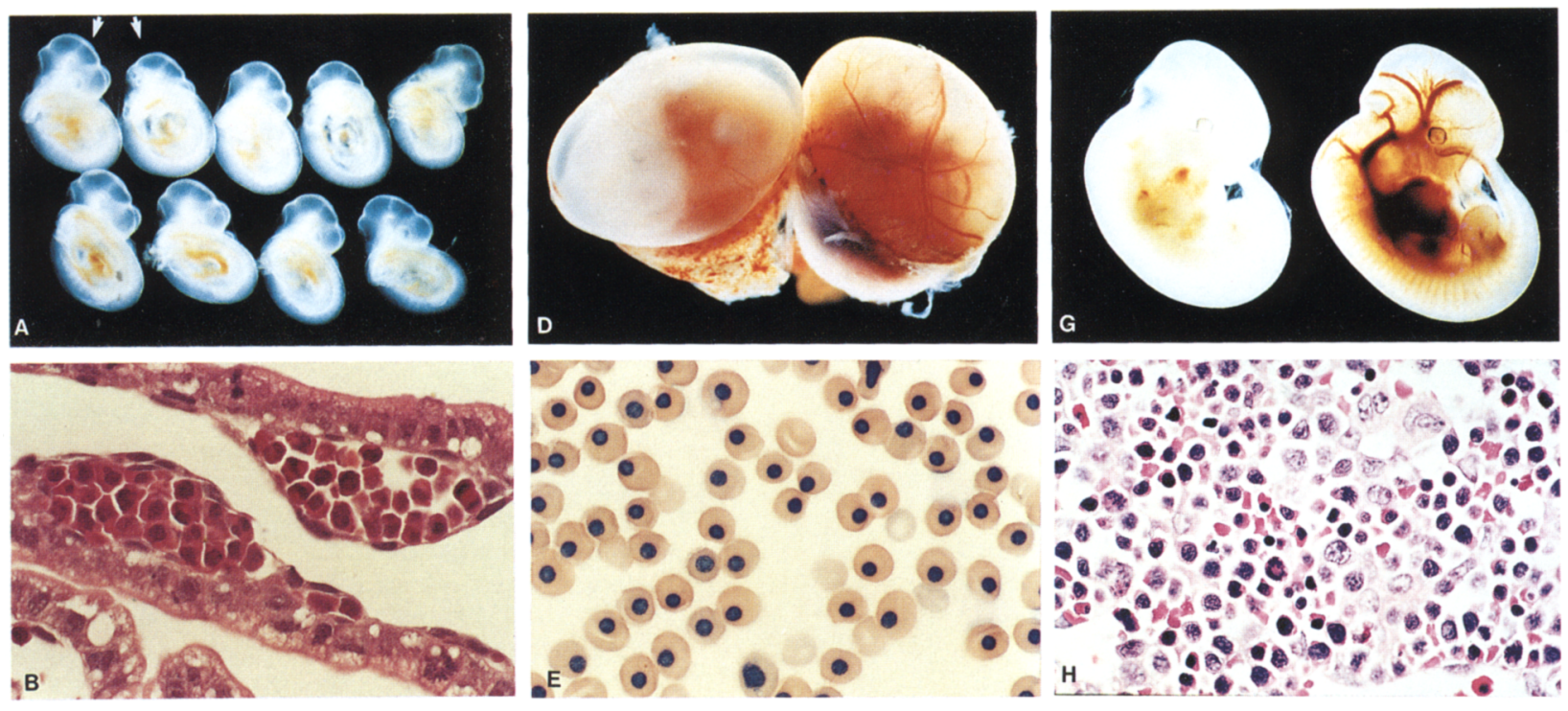

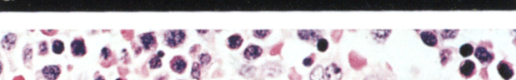

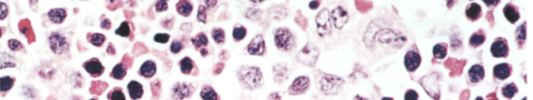

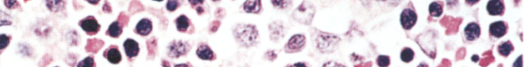

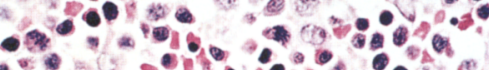

0 - $20.0 \%$
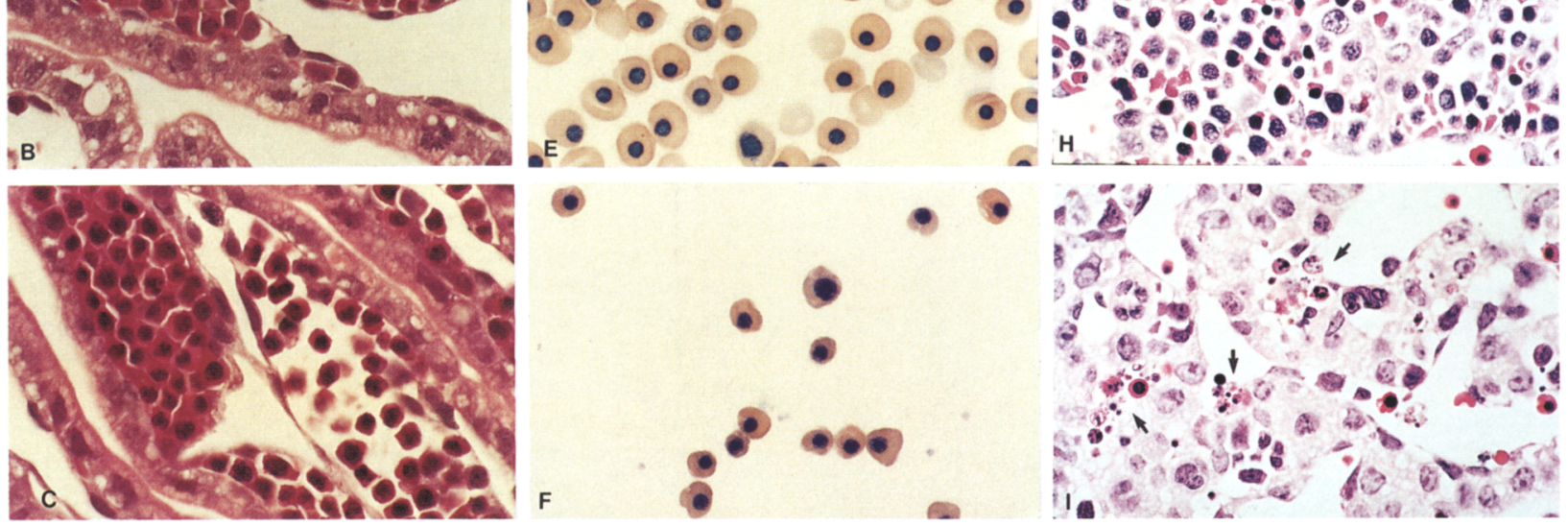

Figure 2. Analysis of erythropoiesis in EpoR - / - and wild-type embryos. (A) Litter of embryos at E9.5, in which the two homozygous mutant embryos (arrows) appear normal. $(B, C)$ Sections of wild-type and mutant yolk sacs, respectively, at E9.5. Note the similar numbers and stage of maturation of primitive erythroblasts. Embryos and yolk sacs were fixed before dissection to prevent loss of blood cells. $(D, G)$ A mutant E1 1.5 embryo (left) and a wild-type littermate (right) before $(D)$ and after $(G)$ removal of the yolk sacs, showing a greatly reduced number of circulating red blood cells in the mutant. $(E, F)$ Smears of circulating blood cells from wild-type and mutant E12.5 embryos, respectively. Mutant primitive erythrocytes show normal nuclear maturation but reduced cellular diameter. Wild-type blood also contains enucleated, definitive red cells, which are absent in the mutant blood (although rare enucleated red cells were observed in some E12.5 mutant blood samples). (H,I) Sections of liver from wild type and mutant E12.5 embryos, respectively. Although the wild-type fetal liver contains large numbers of differentiating erythroid cells (with darkly staining nuclei and eosinophillic cytoplasm), the number in the mutant liver is greatly reduced, and many of these cells display nuclear fragmentation characteristic of apoptosis (arrows). Original magnifications: $(B, C, E, F) 792 \times ;(H, I) 504 \times$. 
Table 1. Properties of hemopoietic tissues in mutant and normal embryos

\begin{tabular}{|c|c|c|c|c|c|c|c|}
\hline \multirow[b]{2}{*}{ Tissue } & \multirow[b]{2}{*}{ Parameter } & & \multirow[b]{2}{*}{ Stage } & \multicolumn{4}{|c|}{ EpoR genotype } \\
\hline & & & & $+1+$ and $+1-$ & $N$ & $-1-$ & $N$ \\
\hline Primitive blood cells & no. per embryo $\left(\times 10^{6}\right)$ & & $\begin{array}{l}\text { E9.5 } \\
\text { E10.5 } \\
\text { E12.5 }\end{array}$ & $\begin{array}{c}0.21 \pm 0.05 \\
1.9 \pm 0.4 \\
3.8 \pm 0.8\end{array}$ & $\begin{array}{l}5 \\
4 \\
7\end{array}$ & $\begin{array}{l}0.17 \pm 0.02 \\
0.27 \pm 0.04 \\
0.37 \pm 0.07\end{array}$ & $\begin{array}{l}2 \\
3 \\
4\end{array}$ \\
\hline Primitive blood cells & $\operatorname{diam} .(\mu \mathrm{m})$ & & $\begin{array}{l}\text { E9.5 } \\
\text { E10.5 } \\
\text { E12.5 }\end{array}$ & $\begin{array}{l}16.1 \pm 0.3 \\
16.0 \pm 1.9 \\
12.9 \pm 0.5\end{array}$ & $\begin{array}{l}2 \\
2 \\
3\end{array}$ & $\begin{array}{l}13.3 \pm 0.1 \\
12.6 \pm 1.4 \\
11.0 \pm 0.5\end{array}$ & $\begin{array}{l}2 \\
3 \\
3\end{array}$ \\
\hline Yolk sac & total no. of cells $\left\langle\times 10^{5}\right\rangle$ & & E10.5 & $1.6 \pm 0.5$ & 7 & $1.5 \pm 0.1$ & 5 \\
\hline Fetal liver & total no. of cells $\left(\times 10^{6}\right)$ & & E12.5 & $4.4 \pm 1.3$ & 7 & $0.39 \pm 0.09$ & 5 \\
\hline Fetal liver & $\begin{array}{l}\text { benzidine-positive (erythroid) cells } \\
\text { benzidine-positive (erythroid) cells } \\
\text { MPO-positive (myeloid) cells } \\
\text { MPO-positive (myeloid) cells } \\
\text { AChE-positive (megakaryocytic) cells } \\
\text { ACh-E-positive (megakaryocytic) cells } \\
\text { mature megakaryocytes } \\
\text { mature megakaryocytes }\end{array}$ & $\begin{array}{l}(\%) \\
\text { (total no.) } \\
(\%) \\
(\text { total no.) } \\
(\%) \\
\text { (total no.) } \\
(\%) \\
\text { (total no.) }\end{array}$ & $\begin{array}{l}\text { E12.5 } \\
\text { E12.5 } \\
\text { E12.5 } \\
\text { E12.5 }\end{array}$ & $\begin{array}{c}45.6 \pm 1.7 \\
2,000,000 \\
0.8 \pm 0.3 \\
35,000 \\
3.5 \pm 0.6 \\
150,000 \\
0.27 \pm 0.12 \\
11,000\end{array}$ & $\begin{array}{l}5 \\
5 \\
3\end{array}$ & $\begin{array}{l}2.1 \pm 0.1 \\
8,200 \\
4.0 \pm 0.5 \\
16,000 \\
5.7 \pm 1.6 \\
22,000 \\
0.45 \pm 0.24 \\
1,800\end{array}$ & $\begin{array}{l}5 \\
5 \\
5 \\
2\end{array}$ \\
\hline
\end{tabular}

Values shown are mean \pm SD. $(N)$ The numbers of independent embryos analyzed.

mulation in the cytoplasm and a progressive condensation of the nucleus. By the criterion of nuclear morphology, the EpoR - / - primitive red blood cells appeared to differentiate normally between E9.5 (Fig. 2B,C) and E12.5 (Fig. 2E,F), although they were somewhat smaller than normal at all stages examined (Table 1). The amount of embryonic $\beta$-globin and $\alpha$-globin per cell, estimated by electrophoresis of globin chains, appeared normal at E10.5 (Fig. 3a) and only slightly lower than normal at E12.5 (Fig. 3b). RT-PCR analyses confirmed that EpoR mRNA was absent in the EpoR-/- yolk sac, and present at a lower level in EpoR + / - than in wild-type yolk sac (Fig. 3c). Erythroid Krüppel-like factor (EKLF) mRNA, a marker of differentiating erythroid cells $a$

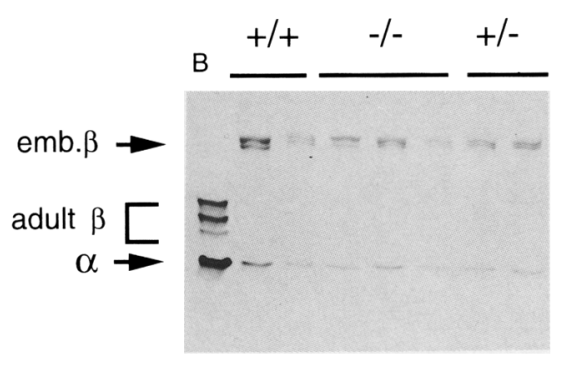

$c$

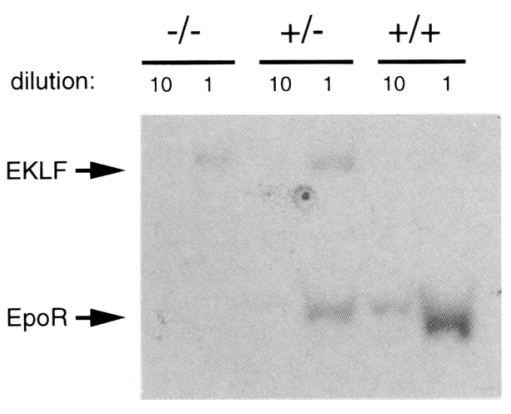

$b$

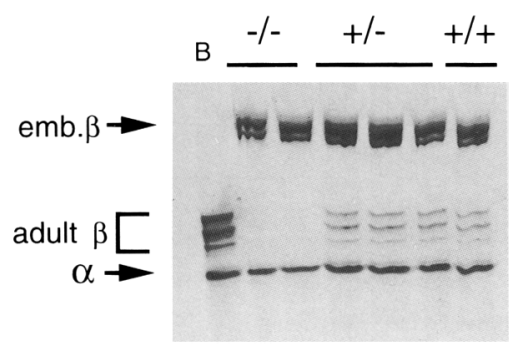

$d$
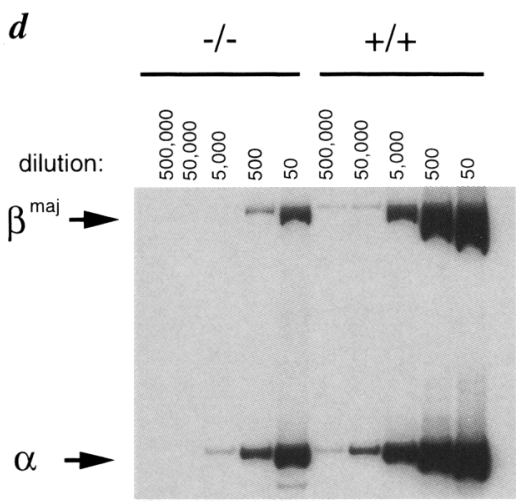

Figure 3. Analysis of gene expression in mutant embryos. $(a, b)$ Electrophoretic analysis of globin chains from blood of E10.5 $|a|$ or E12.5 $(b)$ embryos. The left lanes (B) contain blood from a normal adult mouse. The remaining lanes contain blood from embryos whose EpoR genotype is indicated at top. For E10.5 embryos, $1 \times 10^{5}$ cells were used per lane, and for E12.5 embryos $4 \times 10^{5}$ cells were used per lane. Embryonic $\beta$-like globins $(\beta \mathrm{h}$ l and $\left.\epsilon^{y}\right)$, adult $\beta$-globins $\left(\beta^{\text {single }}, \beta^{\text {major }}\right.$, and $\beta^{\text {minor }}$, and $\alpha$-globin are indicated. The gel shown in $a$ was stained with Coomassie blue; the gel in $b$ with Protostain silver stain (National Diagnostics). (c) RT-PCR analysis of erythroid Krüppel-like factor (EKLF) mRNA and EpoR mRNA in E10.5 yolk sacs of the indicated genotypes. The products are 496 bp (EKLF) and 452 bp (EpoR). (d) RT-PCR analysis of $\alpha$-globin and $\beta^{\text {maj }}$-globin mRNA in E12.5 livers of the indicated genotypes. The products are $331 \mathrm{bp}$ ( $\alpha$-globin) and $578 \mathrm{bp}$ ( $\beta^{\text {mai }}$-globin). The numbers above each lane in $c$ and $d$ indicate the relative dilutions of cDNA added to each PCR reaction. The images shown are autoradiographs of ${ }^{32} \mathrm{P}$-labeled PCR products after separation on polyacrylamide gels. 
(Miller and Bieker 1993), was detected at similar levels in mutant and normal yolk sac samples, providing an internal control for RNA quantities (Fig. 3c). These results indicate that the cytological and molecular differentiation of primitive erythrocytes do not require stimulation through the EpoR.

\section{Development of definitive erythroid cells in EpoR -/- embryos}

The EpoR mutation had far more severe effects on the production of definitive erythrocytes. At E12.5, the stage when enucleated, definitive erythrocytes begin to be released from the fetal liver into the circulation (Russell 1979|, wild-type blood contained $9 \%$ enucleated erythrocytes, although these cells were absent or exceedingly rare in the blood of mutant embryos (Fig. 2E,F). Adult $\beta$-globin chains, which are expressed primarily in definitive red cells, but also at low levels in E12.5 primitive red cells (Brotherton et al. 1979), were readily detected in normal blood at this stage, but barely visible in $-1-$ blood (Fig. 3b), consistent with the absence of definitive erythrocytes.

The normal E12.5 fetal liver consisted largely of erythroid cells at various stages of differentiation (Fig. $2 \mathrm{H})$, and about half of the fetal liver cells stained with benzidine (Table 1), a specific marker for hemoglobin-containing erythroid cells. In contrast, the EpoR - / - liver was small and pale, and the total cell number per liver was reduced 10-fold (Table 1). The percentage of benzidinepositive cells was reduced $>20$-fold (Table 1), and thus the total number of benzidine-positive cells per liver was $>200$-fold below normal. Furthermore, most of the visible erythroid cells were apoptotic, as indicated by their nuclear fragmentation (Fig. 2I; arrows). These results are consistent with an important role for the EpoR in the survival and/or proliferation of definitive erythroid precursors. However, the few mutant erythroblasts present appeared to accumulate hemoglobin, as indicated by their eosinophilic cytoplasm and benzidine staining. In addition, RT-PCR analyses showed that the mutant fetal liver contained low levels of $\alpha$ - and $\beta^{\text {mai }}$-globin mRNA (Fig. 3d). Thus, in the few definitive erythroblasts that are formed in vivo, the absence of the EpoR does not appear to block the early stages of differentiation.

\section{In vitro assays for definitive erythroid progenitors}

In vitro assays for clonogenic erythroid progenitors confirmed the severe effects of the mutation on definitive erythropoiesis, and also indicated that EpoR signaling is critical for the proliferation and/or survival of relatively late erythroid (CFU-E) progenitors but not of earlier erythroid (BFU-E) or multipotential progenitors. Although the only differentiated erythrocytes seen at E10.5 are nucleated cells of the primitive lineage, the erythroid progenitors in the E10.5 yolk sac give rise to definitive erythroid cells when cultured in vitro (Wong et al. 1986), and thus represent early progenitors of the definitive lineage. Similar numbers of red cell-containing bursts were obtained from mutant and wild type E10.5 yolk sac cells cultured for 9 days (Table 2). However, although the wild-type bursts consisted largely of red cells (Fig. 4A), the mutant bursts contained only very small numbers of visibly hemoglobinized cells (Fig. 4C). Many of the erythroid cells in both types of colonies had terminally differentiated to the stage of enucleation (Fig. 4B,D). Most of these bursts also contained some granulocytes, macrophages, and megakaryocytes, and thus derive from multipotential erythroid/myeloid progenitors. Mutant E12.5 livers contained normal numbers of day $7 \mathrm{BFU}-\mathrm{E}$, despite their reduced numbers of total cells and differentiated erythroid cells (Table 2). However, the EpoR - / - erythroid bursts were much smaller and paler than the wild-type bursts (Fig. 5A,E). Examination of stained preparations showed that the mutant bursts contained mature, enucleated erythrocytes (Fig. 5C,G), although in greatly reduced numbers.

When day 2 CFU-E were assayed with Epo as the only added cytokine (the traditional assay for CFU-E), the number of red cell colonies derived from mutant E12.5 livers was 13-fold below normal (Table 2), and the colony size was smaller. However, because Epo can support colony formation by normal CFU-E, but presumably not the EpoR-1- CFU-E, such an assay cannot measure the number of mutant erythroid progenitors that have developed to the CFU-E stage. Therefore, as an alternative assay for CFU-E, mutant and wild-type fetal liver cells

Table 2. Hemopoietic progenitors in yolk sacs and fetal livers

\begin{tabular}{lcc}
\hline & \multicolumn{2}{c}{ EpoR genotype } \\
\cline { 2 - 3 } & $+1+$ and $+/-$ & $-/-$ \\
\hline E10.5 yolk sac & $50 \pm 21$ & $43 \pm 9$ \\
BFU-eryth/mix & $50 \pm 14$ & $38 \pm 4$ \\
CFU-mega & & \\
E12.5 fetal liver & $5,300 \pm 1,600$ & $5,400 \pm 1,300$ \\
BFU-E & $106,000 \pm 56,000$ & $43,000 \pm 8,100$ \\
CFU-E & $90,000 \pm 26,000$ & $6,800 \pm 1,600$ \\
CFU-E (Epo only) & $5,400 \pm 1,600$ & $6,000 \pm 1,400$ \\
CFU-GM & $1,500 \pm 200$ & $1,400 \pm 300$ \\
CFU-mega &
\end{tabular}

Each value presented is a mean number per liver or yolk sac, \pm S.D., based on duplicate determinations on each of three or four independent yolk sacs or livers. (CFU-mega) Megakaryocyte colony-forming-units; (BFU-eryth/mix) multipotential progenitors that gave rise to large bursts containing erythroid cells as well as some granulocytes and macrophages (e.g., Fig. 4A-D). They were counted 9 days after plating $2 \times 10^{4}$ yolk sac cells per dish, and their numbers were corrected for the total numbers of cells in the yolk sac (Table 1). Fetal liver CFU-E and BFU-E were counted 2 or 7 days, respectively, after plating $2 \times 10^{4}$ cells per dish, and their numbers were corrected for the total cell numbers in mutant and wild-type fetal livers (Table 1). CFU-E (Epo only) cultures lacked SCF and SCM (see Materials and methods). (CFU-GM) Colonies including granulocytes and/or macrophages but no visible erythroid cells. Wild-type $(+1+)$ and heterozygous $(+1-)$ cells gave indistinguishable results in all colony assays, and these data were therefore combined. 


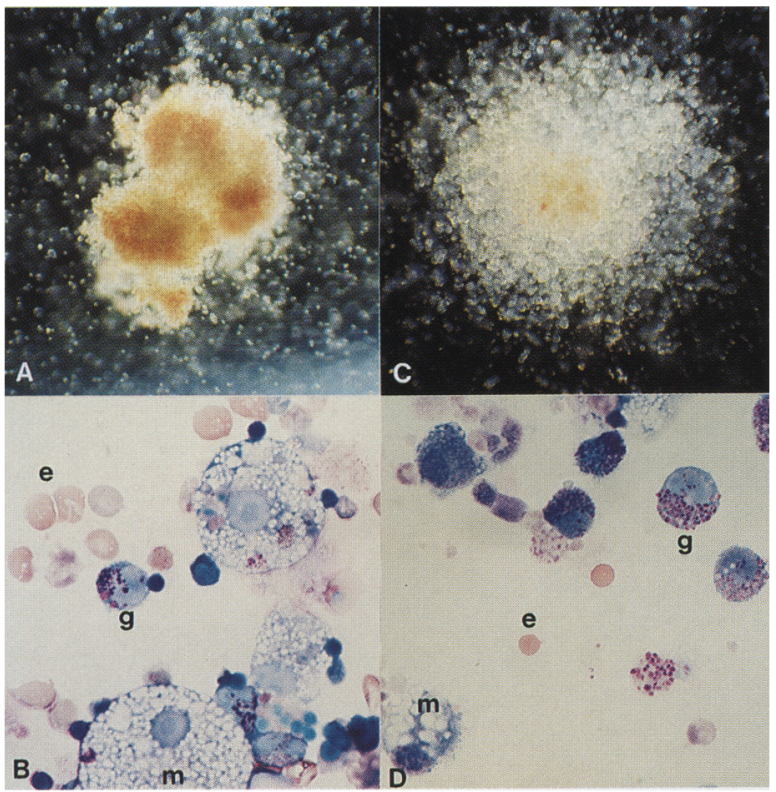

Figure 4. In vitro culture of definitive erythroid cells and myeloid cells from EpoR - / - and wild-type E10.5 yolk sacs. $(A)$ Day 9 burst, consisting primarily of hemoglobinized erythroid cells, derived from a wild type yolk sac. $(B)$ High-magnification view of cells from $A$, including erythrocytes (e), macrophages $(\mathrm{m})$, and granulocytes $(\mathrm{g})$. (C) Day 9 burst derived from a mutant yolk sac, containing only a few red cells. $(D)$ High-magnification view cells from $C$, including erythrocytes, macrophages, and granulocytes. Original magnifications: $(A, C) 45 \times ;(B, D) 504 \times$.

were cultured in medium supplemented with stem cell factor ( $\mathrm{SCF})$ and spleen cell-conditioned medium [SCM, a source of interleukin-3 (IL-3) and other cytokines] as well as Epo, and day 2 erythroid colonies were scored. Under these conditions, the number of CFU-E in mutant E12.5 livers was only about twofold below normal (Table 2), although the mutant colonies remained smaller and paler than normal CFU-E colonies (Fig. $5 B, F)$, suggesting that proliferation and differentiation after the CFU-E stage was reduced. The number of 2-day CFU-E detected in wild-type fetal livers was unchanged by the addition of SCF and SCM (Table 2), indicating that these factors do not cause a different population of erythroid progenitors to be counted as CFU-E, but rather allow the mutant CFU-E to survive, proliferate, and differentiate in the absence of Epo. Additional control experiments showed that the number and size of mutant CFU-E colonies was insensitive to the presence or absence of Epo, as expected, whereas the wild-type CFU-E were Epo-dependent (i.e., in the absence of Epo, the number and size of wild-type CFU-E colonies were reduced to those seen with EpoR - / - fetal livers; data not shown).

\section{Effects of the EpoR mutation on adult erythropoiesis}

Because homozygous mutant embryos died at E13.5, the effects of the mutation on hemopoiesis in adult mice could not be assessed directly. As an alternative strategy, we produced chimeric mice by microinjection of $+1+$, $+/-$, or $-1-$ ES cells into wild-type blastocysts, and then analyzed ES cell contributions to adult whole blood and blood cell fractions (Fig. 6; data not shown). The $+/+$ ES cells contributed to all fractions, as expected (Fig. 6a). In contrast, the $-/-$ cells failed to contribute to the red cell fraction at a detectable level (Fig. 6c), although they contributed extensively to the white cell

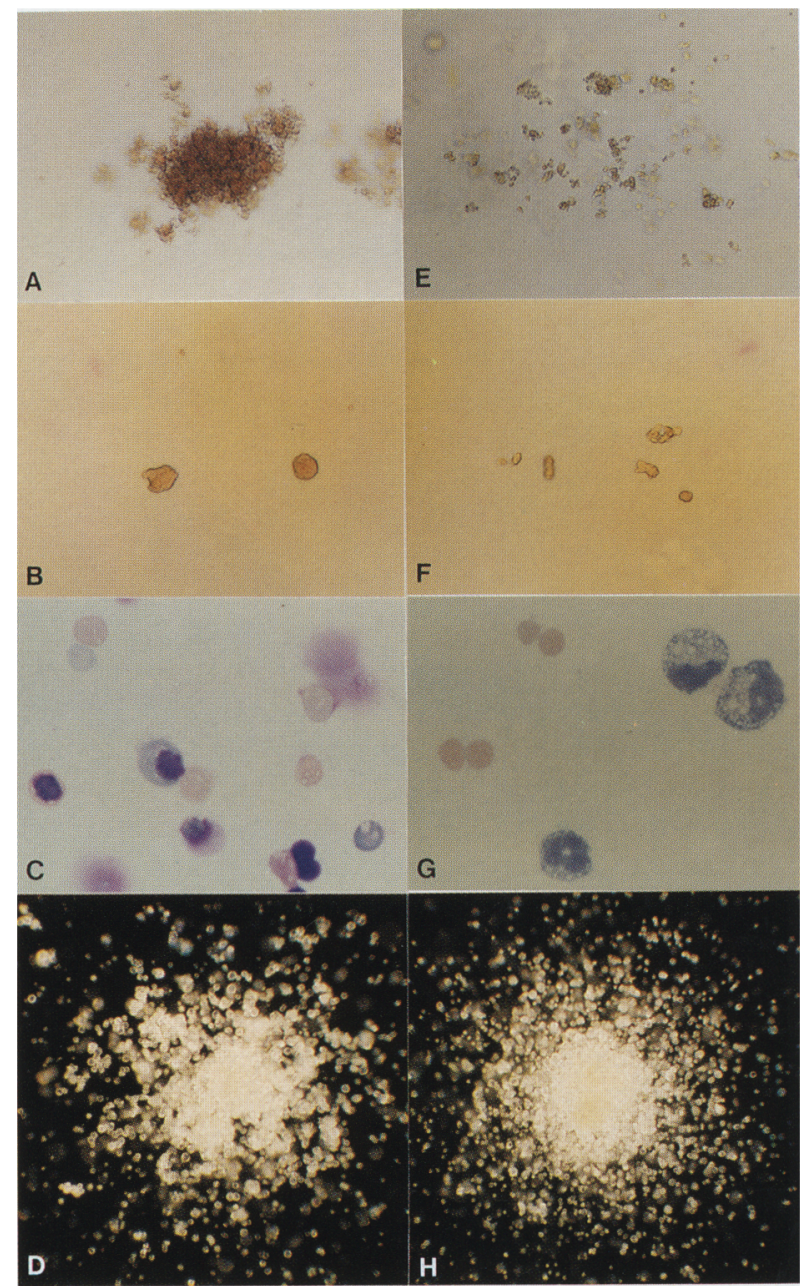

Figure 5. In vitro assay of erythroid (BFU-E and CFU-E) and myeloid (CFU-GM) progenitors from wild type $(A-D)$ or EpoR $-/-(E-H)$ E12.5 fetal livers. $(A, E)$ A wild-type and a mutant day 7 erythroid burst. Note the reduced cell number in the mutant burst. $(B, F)$ Two wild-type and 5-6 mutant day 2 (CFUE-derived) erythroid colonies, grown in the presence of Epo, SCF, and SCM. Note the reduced size of the mutant colonies. $(C, G)$ Smears of cells from a wild-type erythroid burst $(C)$ or a mutant erythroid/mixed burst $(G)$. The wild-type burst includes nucleated erythroblasts and enucleated erythrocytes, whereas the mutant burst includes enucleated erythrocytes as well as myeloid cells. $(D, H)$ A wild-type and a mutant granulocyte/ macrophage colony. Original magnifications: $(A, B, E, F) 112 \times$; $(C, G) 654 \times ;(D, H) 90 \times)$. 
Figure 6. Contribution of EpoR $+1+(a)$, EpoR $+/-(b)$, and EpoR $-/-(c)$, ES cells to the blood cells of chimeric adult mice, determined by glucose phosphate isomerase (GPI) enzyme assay after electrophoretic separation of GPI-1 isozymes A and C. ES-derived cells produce GPI-1C, whereas host blastocyst-derived cells produce GPI-1A. (B) Whole blood; $(\mathrm{R})$ red cell fraction; (W) white cell fraction; $(\mathrm{P})$ platelets. $\boldsymbol{a}$

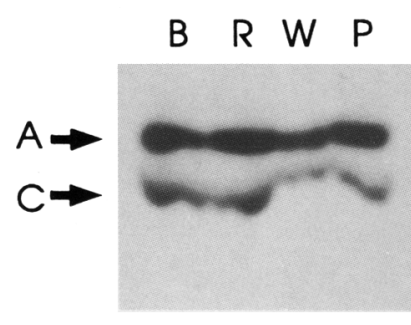

b

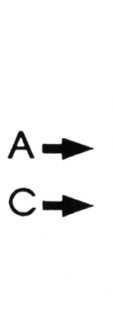

c B R W P $\rightarrow \underset{C \rightarrow C}{A \rightarrow}$

\section{B R W P}

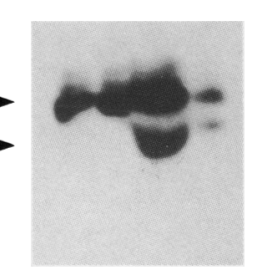

fraction, confirming the important role of Epo in adult erythropoiesis. Surprisingly, EpoR heterozygous $(+/-)$ ES cells contributed very weakly, or not at all, to the red cell fraction, although they contributed strongly to the white cells (Fig. 6b). As heterozygous (nonchimeric) EpoR $+/$ - mice had normal hematocrits, the $+/$ - cells must be competent to differentiate into red cells. Thus, the results suggest that in a chimeric environment containing EpoR $+/+$ and $+/$ - cells, the EpoR $+/$ - erythroid progenitors are at a competitive disadvantage, perhaps because proliferation is slightly decreased due to a reduced number of EpoR molecules.

\section{Effects of the EpoR mutation on nonerythroid cells}

To examine the importance of the EpoR for megakaryocytopoiesis, megakaryocyte progenitors in E10.5 yolk sacs and E12.5 fetal livers were measured using a colony assay. The total number of CFU-megakaryocyte per mutant yolk sac or fetal liver did not differ significantly from wild-type values (Table 2). In mutant fetal livers, acetylcholinesterase-positive cells (i.e., megakaryoblasts plus megakaryocytes) and morphologically differentiated megakaryocytes were slightly increased as a percentage of total cells, and reduced six- to sevenfold in absolute numbers (Table 1). Importantly, EpoR - / - ES cells contributed to the platelet fraction in chimeric mice (Fig 6c), indicating that the EpoR is not required for the terminal differentiation of megakaryocytes.

To examine myelopoiesis in the fetal liver, the percentage of cells positive for myeloperoxidase (MPO, a marker of promyelocytes and maturing granulocytes and macrophages| was determined. The percentage of MPOpositive cells was fivefold higher in mutant than wildtype E12.5 fetal livers (Table 1), and thus the absolute number of such cells per liver was reduced only twofold. The number of myeloid progenitors [CFU-granulocytemacrophage (CFU-GM)] per mutant liver was also close to the wild-type value (Table 2), and the ability of granulocytes and macrophages to differentiate in vitro appeared normal (Figs. 4D and 5G; data not shown). Furthermore, unlike the erythroid colonies, the mutant and wild-type granulocyte/macrophage colonies developed to similar sizes (e.g., Fig. 5D,H), indicating a normal proliferative capacity.

The vascular endothelium of E9.5-E11.5 mutant em- bryos and yolk sacs also appeared normal by histological criteria (e.g., Fig 2B,C).

\section{Discussion}

To investigate the role of signaling through the erythropoietin receptor in primitive and definitive erythropoiesis, as well as in the development and differentiation of other cell types, we have analyzed developing mouse embryos homozygous for a targeted deletion within the EpoR gene. We have also examined the ability of homozygous mutant embryonic stem cells to contribute to blood cell lineages in chimeric adult mice. Our studies reveal that primitive erythropoiesis in the yolk sac is considerably less dependent on EpoR signaling than is definitive erythropoiesis. Definitive erythropoiesis in the fetal liver is reduced drastically by the mutation, as is the ability of homozygous mutant ES cells to participate in definitive erythropoiesis in the chimeric adult. In vitro colony assays suggest that the stage of definitive erythropoiesis at which EpoR signaling begins to play an essential role is the CFU-E, a relatively mature erythroid precursor. However, further differentiation is not completely blocked, particularly when embryonic hemopoietic cells are cultured in the presence of additional cytokines that may substitute for some of the functions of Epo.

At early stages of yolk sac erythropoiesis (through E9.5), the number of primitive erythrocytes in the yolk sac and in the circulation was unaffected by the EpoR mutation. Furthermore, these cells continued to differentiate over the next 3 days, accumulating near normal levels of globin and undergoing normal nuclear maturation. Their only obvious defect was a slight reduction in size. This supports several previous observations that primitive erythropoiesis in cultured yolk sacs could proceed in the absence of added Epo (Cole and Paul 1966; Ripoche and Cudennec 1983; Labastie et al. 1984). However, although the synthesis of endogenous Epo could not be excluded in the previous studies, the possible presence of Epo was irrelevant in our experiments because of the absence of a functional EpoR gene. It remains to be determined whether in the early primitive lineage, another cytokine/receptor pair may serve an analogous role to that of Epo and EpoR in the definitive erythroid lineage. Although gene targeting studies have 
identified several nuclear factors that are required for development of the primitive erythroid lineage /Simon et al. 1992; Tsai et al. 1994; Warren et al. 1994; Weiss et al. 1994; Shivdasani et al. 1995), no cytokine or receptor mutants that block primitive erythropoiesis have yet been reported. Mutations at the $W$ and $S I$ loci have only mild effects on the proliferation of primitive erythrocytes (Russell et al. 1968; Chui and Russell 1974), indicating that the $c$-kit receptor and its ligand SCF do not play an essential role in the development of this lineage.

At later stages in the development of the primitive erythroid lineage, the EpoR begins to play a more important role, as the proliferation of these cells becomes markedly reduced in its absence. This transition from EpoR independence to dependence in the murine primitive erythroid lineage coincides with an increase in the number of EpoR molecules per cell during the corresponding period of hamster primitive erythropoiesis (Boussios et al. 1989). It may also explain why primitive erythroid cells appeared to respond to Epo in some previous studies (Bateman and Cole 1971; Keller et al. 1993) but not in others (Cole and Paul 1966; Ripoche and $\mathrm{Cu}$ dennec 1983; Labastie et al. 1984). It is interesting to note that normal murine primitive erythrocytes, which initially express only embryonic hemoglobins, also begin to express small amounts of adult hemoglobin after E11.5 (Brotherton et al. 1979). Thus, during their maturation primitive erythrocytes appear to acquire gradually several properties characteristic of definitive erythroid cells, one of which is a dependence on Epo for normal proliferation.

From the earliest stages of definitive erythropoiesis, the production of differentiated (i.e., benzidine-positive) fetal liver erythroblasts was reduced $>200$-fold by the EpoR mutation, confirming the role of Epo in promoting cell survival and proliferation in this lineage. A variety of evidence from previous studies has identified the CFU-E and the more mature erythroblast as the stages at which erythroid cells are most sensitive to and dependent on Epo. Early BFU-E appear to be Epo independent, and Epo dependence is generally observed to arise at a stage somewhere between the late BFU-E and the early CFU-E (Gregory 1976; Iscove 1977; Krantz 1991; Youssoufian et al. 1993). In the EpoR - / - mutant, the normal numbers of fetal liver BFU-E suggests that the EpoR does not play an essential role in any hemopoietic cell earlier than the BFU-E, nor does it stimulate commitment of multipotential cells to the erythroid lineage. On the other hand, the paucity of viable, maturing fetal liver erythroblasts in vivo, as well as the reduced cell numbers in CFU-Ederived colonies in vitro, demonstrate the importance of signaling through the EpoR for the proliferation and survival of erythroid cells at and beyond the CFU-E stage. However, the observation that near-normal numbers of CFU-E were formed in the EpoR - / - fetal livers suggests that cells earlier than the CFU-E (i.e., those giving rise to CFU-E) do not require EpoR signaling for normal proliferation.

It is also interesting to note that although few of the mutant definitive erythroid cells appeared to mature be- yond an undifferentiated precursor stage in vivo, a fraction of these cells could reach various stages of terminal differentiation (i.e., production of well-hemoglobinized erythroblasts, or even enucleated erythrocytes) when cultured in vitro, particularly when additional cytokines were provided. Thus, our results show that signaling through the EpoR is not an obligatory step in the regulatory pathway leading to red cell differentiation, either in the definitive or in the primitive lineage. The ability of the mutant BFU-E and CFU-E to produce hemoglobinized red cells under these conditions is consistent with reports that SCF or IL-3 could support the differentiation of normal erythroid precursors in the absence of added Epo (Goodman et al. 1985; Papayannopoulou et al. 1993). On the other hand, the few EpoR-1 - definitive erythrocytes that developed in vitro appeared to be smaller and less hemoglobinized than those in wild-type colonies. This mild microcytosis is reminiscent of that seen in iron-deficiency anemias and other conditions leading to reduced hemoglobin production in humans (Hoffman et al. 1991), which is consistent with the reported ability of Epo to stimulate heme and globin synthesis in definitive erythroid cells (Cole and Paul 1966; Bondurant et al. 1985; Nijhof et al. 1987).

No clear evidence of a developmental requirement for EpoR in any nonerythroid cell lineage was obtained in these studies. The number of myeloperoxidase-positive myeloid cells in the E12.5 mutant fetal liver was close to normal, as was the number of myeloid progenitors (CFUGM) and their ability to form colonies in vitro. The endothelial cells of the yolk sac and embryo also appeared to be unaffected by the mutation, although more detailed studies will be needed to examine the possibility of subtle effects. In the megakaryocyte lineage, although the number of CFU-megakaryocyte per liver was normal, the total numbers of megakaryoblasts and mature megakaryocytes were reduced sevenfold in mutant fetal livers. This is consistent with data that Epo can stimulate megakaryocyte proliferation and platelet production (McDonald et al. 1987; Berridge et al. 1988), although it could also be an indirect effect of the mutation. In either case, the observation that EpoR - / - ES cells could contribute to the platelets in chimeric mice demonstrates that Epo/EpoR signaling is not required for terminal differentiation in this lineage.

In conclusion, the generation of EpoR-deficient mice and ES cells has provided a new tool to investigate the role of EpoR signaling in the development of the erythroid and other cell lineages. Our studies have revealed a differential role for EpoR signaling in definitive versus primitive erythropoiesis, and have confirmed its importance for the survival and proliferation of late stage definitive erythroid progenitors. The mutant mice, as well as the homozygous mutant ES cells, which display defects in hemopoiesis in vitro (C.-S. Lin and F. Costantini, unpubl.), will also provide a useful system to test the function of mutant forms of the EpoR (Barber and D'Andrea 1992; Youssoufian et al. 1993) in normal erythropoiesis. 
Lin et al.

\section{Materials and methods \\ Targeted disruption of the EpoR gene}

A 1.9-kb EcoRI fragment and a 6.5-kb HindIII fragment of the EpoR gene (Fig. la), isolated from a 129/SvEv mouse DNA library, were cloned into the EcoRI and XhoI sites, respectively, of the pPNT vector (Tybulewicz et al. 1991), which contains the herpes simplex virus thymidine kinase (HSV $T K$ ) and phosphoglycerokinase-neomycin (PGK neo) genes. The linearized targeting vector was electroporated into CCE ES cells (Robertson et al. 1986), which were selected with G418 and Gancyclovir. Chimeric male mice, generated by injecting the heterozygous mutant ES cells into C57BL/6J blastocysts, were mated to $\mathrm{C} 57 \mathrm{BL} / 6 \mathrm{~J}$ females. Heterozygous mutant progeny were intercrossed, and the resulting embryos were genotyped by Southern or PCR analysis. Homozygous mutant (EpoR-1-) ES cells were produced by growing EpoR $+/-$ ES cells in $2.5 \mathrm{mg} / \mathrm{ml}$ of G418 (Mortensen et al. 1992), and identifying by Southern analysis surviving clones that had converted to EpoR - / - . Embryos from intercrosses between EpoR $+1-$ mice were genotyped by Southern or PCR analysis (Fig. 1) of DNA isolated from yolk sac or embryonic tissue. The PCR primers used were P1, 5'-gccccctctgtctcctactt-3'; P2， 5'-cgcctcaaaaccagaaacag-3'; P3, 5'gaagagcttggcggcgaatg- $3^{\prime}$; and amplification was performed using 15 pmoles of each primer, in a volume of $50 \mu \mathrm{l}$, for 33 cycles of $94^{\circ} \mathrm{C}, 30 \mathrm{sec}, 64^{\circ} \mathrm{C}, 10 \mathrm{sec}, 72^{\circ} \mathrm{C}, 90 \mathrm{sec}$, followed by $5 \mathrm{~min}$ at $72^{\circ} \mathrm{C}$.

\section{Analysis of hemopoiesis in mutant embryos}

For histological analysis, whole embryos were fixed in $4 \%$ paraformaldehyde, and yolk sacs or fetal livers were removed, embedded in paraffin, sectioned at $2 \mu \mathrm{m}$, and stained with hematoxylin-eosin (H\&E). To count cells of the erythroid, myeloid, and megakaryocyte lineages, fetal livers were disaggregated mechanically (Jordan et al. 1990), and the cells were applied to slides by cytocentrifugation and stained by one of several methods. Benzidine staining (Borsook et al. 1969) was used to detect erythroid cells; staining for myeloperoxidase enzyme activity (Kaplow 1965) served as a marker of promyelocytes, granulocytes, and macrophages (Koeffler et al. 1985); and staining for acetylcholinesterase enzyme activity provided a marker for megakaryoblasts and megakaryocytes (Williams et al. 1981). For each stain, 10 high-powered fields (63× objective) were photographed and the numbers of stained cells as well as the total number of cells per field were counted. Mature megakaryocytes were counted independently in H\&E-stained fetal liver sections based on their large size and nuclear hyperlobation.

For examination of erythrocyte morphology and measurements of cell size, blood cells were collected from the umbilical cord of E10.5 and E12.5 embryos, or from the heart region of E9.5 embryos, after extensive washing of the embryo in phosphate-buffered saline (PBS) to remove any maternal blood cells. Smears were prepared and stained with May-Grunwald-Giemsa, and primitive erythrocyte diameters were measured using an eye-piece micrometer. For determination of blood cell numbers, E10.5 or E12.5 embryos were allowed to bleed terminally into a known volume of PBS, and the blood cells were counted in a hemocytometer. The E9.5 embryos were minced in PBS with fine forceps to release the blood cells, which were stained with benzidine by adding $25 \mu \mathrm{l}$ of benzidine solution and $25 \mu \mathrm{l}$ of peroxide solution (Borsook et al. 1969) to $50 \mu$ l of cell suspension. After $5 \mathrm{~min}$ at room temperature, the benzidine-positive (orange-brown) cells were counted in a hemocytometer. Total yolk sac and fetal liver cells were counted in a hemocytometer after preparation of single cell suspensions.

\section{Analysis of globin chains and mRNA in embryonic blood and fetal livers}

For globin chain analysis, embryonic blood samples were lysed and globin chains were separated by acid urea-Triton-polyacrylamide gel electrophoresis, as described (Rovera et al. 1978). For reverse transcription PCR (RT-PCR), first-strand cDNA synthesis using oligo (dT) primer was carried out as described in the manufacturer's protocol (GIBCO-BRL-Superscript Preamplification system for first-strand cDNA synthesis), using total cellular RNA isolated from $3.75 \times 10^{4}$ yolk sac cells or $2 \times 10^{5}$ fetal liver cells. The PCR reactions were carried out according to the procedure of Weiss et al. (1994) using the primers described in that reference to detect EpoR transcripts (Fig. 3c) or $\alpha$-globin and $\beta^{\text {mai }}$-globin (Fig. 3d). EKLF transcripts were detected using the primers $5^{\prime}$-gacgcaggcttgtccccggg- 3 ' and $5^{\prime}$-gggccatgtgtggggctccc- $3^{\prime}$ and the same reaction conditions. For $\alpha$-globin and $\beta^{\text {mai }}$ globin PCR, the conditions were modified to $\left(94^{\circ} \mathrm{C}, 30 \mathrm{sec}, 60^{\circ} \mathrm{C}\right.$, $10 \mathrm{sec}$, and $\left.72^{\circ} \mathrm{C}, 80 \mathrm{sec}\right)$. The PCR reactions contained quantities of cDNA equivalent to those derived from 180 or 1800 yolk sac cells (Fig. 3c), or $0.5,5,50,500$, or 5000 fetal liver cells (Fig. $3 \mathrm{~d})$. The PCR reactions were carried out for 30 cycles in the presence of $\left[{ }^{32} \mathrm{P}\right] \mathrm{dCTP}$, and the products were electrophoresed through a $5 \%$ polyacrylamide gel and visualized by autoradiography.

\section{Analysis of chimeric mice}

Chimeric adult mice were produced by microinjection of EpoR $+/+,+1-$, or $-1-$ ES cells (homozygous gpi-1c) into strain MF1 blastocysts (gpi-1a), and were identified initially by coat color chimerism. Red and white blood cell fractions were separated by centrifugation, platelets were purified by differential sedimentation and Sepharose 2B chromatography, and glucose phosphate isomerase (GPI) isozymes were analyzed, as described previously (Pevny et al. 1995). The analyses of whole blood, and red and white cell fractions were performed with four chimeras produced with EpoR - / - ES cells, four chimeras with EpoR +1 - cells, and two chimeras produced with EpoR - / cells. Platelets from two chimeric mice of each type were analyzed.

\section{Assays for colony forming cells in yolk sacs and fetal livers}

Yolk sacs were disaggregated individually to single cells by treatment with collagenase (Wong et al. 1986; Pevny et al. 1995) and aliquots of $4 \times 10^{4}$ cells were plated in $1.5-\mathrm{ml}$ cultures containing $0.8 \%$ methylcellulose, $30 \%$ fetal bovine serum (FBS) and $1 \%$ BSA (Stem Cell Technologies), plus $20 \mathrm{ng} / \mathrm{ml}$ of recombinant rat SCF (Amgen), 1.5\% pokeweed mitogen-stimulated SCM (Stem Cell Technologies), and $2 \mathrm{U} / \mathrm{ml}$ of recombinant human Epo (R\&D Systems), as described (Pevny et al. 1995). Fetal livers were disaggregated mechanically (Jordan et al. 1990) and BFU-E, CFU-E, and CFU-GM were assayed by the same methods used for yolk sac cells. Cultures for assay of BFU-E and CFU-GM contained Epo, SCF, and SCM, and cultures for assay of CFU-E contained either Epo alone, Epo plus SCF and SCM, or no added factors, as described in the text and the legend to Table 2. For microscopic examination, colonies were picked with a micropipet, dispersed in PBS, and smeared on slides or applied to slides by cytocentrifugation at $600 \mathrm{rpm}$ for $5 \mathrm{~min}$. To measure CFU-megakaryocyte, yolk sac or fetal liver cells were cultured in agar cultures as described (Pevny et al. 1995) and stained for acetylcholines terase (Williams et al. 1981). 


\section{Acknowledgments}

We thank Stephen Tsang for helpful discussions and Arthur Bank for comments on the manuscript. This work was supported by a grant from the National Institutes of Health to F.C. and a Special Fellowship from the Leukemia Society of America to S.-K.L.

The publication costs of this article were defrayed in part by payment of page charges. This article must therefore be hereby marked "advertisement" in accordance with 18 USC section 1734 solely to indicate this fact.

\section{References}

Anagnostou, A., E.S. Lee, N. Kessimian, R. Levinson, and M. Steiner. 1990. Erythropoietin has a mitogenic and positive chemotactic effect on endothelial cells. Proc. Nat1. Acad. Sci. 87: 5978-5982.

Anagnostou, A., Z. Liu, M. Steiner, K. Chin, E.S. Lee, N. Kessimian, and C.T. Noguchi. 1994. Erythropoietin receptor mRNA expression in human endothelial cells. Proc. Natl. Acad. Sci. 91: 3974-3978.

Barber, D.L. and A.D. D'Andrea. 1992. The erythropoietin receptor and the molecular basis of signal transduction. Semin. Hematol. 29: 293-304.

Bateman, A.E. and R.J. Cole. 1971. Stimulation of haem synthesis by erythropoietin in mouse yolk-sac-stage embryonic cells. J. Embryol. Exp. Morphol. 26: 475-480.

Bazan, J.F. 1990. Structural design and molecular evolution of a cytokine receptor superfamily. Proc. Natl. Acad. Sci. 87: 6394-6398.

Berridge, M.V., J.K. Fraser, J.M. Carter, and F.K. Lin. 1988. Effects of recombinant human erythropoietin on megakaryocytes and on platelet production in the rat. Blood 72: 970977.

Bondurant, M.C., R.N. Lind, M.J. Koury, and M.E. Ferguson. 1985. Control of globin gene transcription by erythropoietin in erythroblasts from friend virus-infected mice. Mol. Cell. Biol. 5: 675-683.

Borsook, H., K. Ratner, and B. Tatirie. 1969. Studies on erythropoiesis II. A method of segregating immature from mature adult rabbit erythroblasts. Blood 34: 32-41.

Boussios, T., J.F. Bertles, and E. Goldwasser. 1989. Erythropoietin receptor characteristics during the ontogeny of hamster yolk sac erythroid. J. Biol. Chem. 264: 16017-16021.

Brotherton, T.W., D.H.K. Chui, J. Gauldie, and M. Patterson. 1979. Hemoglobin ontogeny during normal mouse fetal development. Proc. Nat1. Acad. Sci. 76: 2853-2857.

Chui, D.H. and E.S. Russell. 1974. Fetal erythropoiesis in steel mutant mice. I. A morphological study of erythroid cell development in fetal liver. Dev. Biol, 40: 256-269.

Cole, R.J. and J. Paul. 1966. The effects of erythropoietin on haem synthesis in mouse yolk sac and cultured foetal liver cells. J. Embryol. Exp. Morphol. 15: 245-260.

Craig, M.L. and E.S. Russell. 1964. A developmental change in hemoglobins correlated with an embryonic red cell population in the mouse. Dev. Biol. 10: 191-201.

D'Andrea, A.D., H.F. Lodish, and G.G. Wong. 1989. Expression cloning of the murine erythropoietin receptor. Cell 57: 277285.

Fraser, J.K., A.S. Tan, F.K. Lin, and M.V. Berridge. 1989. Expression of specific high-affinity binding sites for erythropoietin on rat and mouse megakaryocytes. Exp. Hematol. 17: 10-16.

Godin, I.E., P.J. Garcia, A. Coutinho, L.F. Dieterlen, and M.A. Marcos. 1993. Para-aortic splanchnopleura from early mouse embryos contains Bla cell progenitors. Nature 364: 67-70.

Godin, I., L.F. Dieterlen, and A. Cumano. 1995. Emergence of multipotent hemopoietic cells in the yolk sac and paraaortic splanchnopleura in mouse embryos, beginning at 8.5 days postcoitus. Proc. Natl Acad. Sci. 92: 773-777.

Goodman, J.W., E.A. Hall, K.L. Miller, and S.G. Shinpock. 1985. Interleukin 3 promotes erythroid burst formation in "serumfree" cultures without detectable erythropoietin. Proc. Natl. Acad. Sci. 82: 3291-3295.

Gregory, C.J. 1976. Erythropoietin sensitivity as a differentiation marker in the hemopoietic system: Studies of three erythropoietic colony responses in culture. $J$. Cell. Physiol. 89: 289-301.

Heberlein, C., K.D. Fischer, M. Stoffel, J. Nowock, A. Ford, U. Tessmer, and C. Stocking. 1992. The gene for erythropoietin receptor is expressed in multipotential hematopoietic and embryonal stem cells: Evidence for differentiation stage-specific regulation. Mol. Cell. Biol. 12: 1815-1826.

Hoffman, R., E.J. Benz Jr., S.J. Shattil, B. Furie, and H.J. Cohen. 1991. Hematology. Basic principles and practice. Churchill Livingstone, New York, NY.

Ihle, J.N., F.W. Quelle, and O. Miura. 1993. Signal transduction through the receptor for erythropoietin. Semin. Immunol. 5: 375-389.

Iscove, N.N. 1977. The role of erythropoietin in regulation of population size and cell cycling of early and late erythroid precursors in mouse bone marrow. Cell Tissue Kinet. 10: $323-334$

Ishibashi, T., J.A. Koziol, and S.A. Burstein. 1987. Human recombinant erythropoietin promotes differentiation of $\mathrm{mu}-$ rine megakaryocytes in vitro. J. Clin. Invest. 79: 286-289.

Jordan, C.T., J.P. McKearn, and I.R. Lemischka. 1990. Cellular and developmental properties of fetal hematopoietic stem cells. Cell 61: 953-963.

Kaplow, L.S. 1965. Simplified myeloperoxidase stain using benzidine dihydrochloride. Blood 26: 215-219.

Keller, G., M. Kennedy, T. Papayannopoulou, and M.V. Wiles. 1993. Hematopoietic commitment during embryonic stem cell differentiation in culture. Mol. Cell. Biol. 13: 473-486.

Koeffler, H.P., J. Ranyard, and M. Pertcheck. 1985. Myeloperoxidase: Its structure and expression during myeloid differentiation. Blood 65: 484-491.

Krantz, S.B. 1991. Erythropoietin. Blood 77: 419-434.

Labastie, M.C., J.P. Thiery, and D.N. Le. 1984. Mouse yolk sac and intraembryonic tissues produce factors able to elicit differentiation of erythroid burst-forming units and colonyforming units, respectively. Proc. Natl. Acad. Sci. 81: 14531456.

Liu, Z.Y., K. Chin, and C.T. Noguchi. 1994. Tissue specific expression of human erythropoietin receptor in transgenic mice. Dev. Biol. 166: 159-169.

Masuda, S., M. Nagao, K. Takahata, Y. Konishi, F.J. Gallyas, T. Tabira, and R. Sasaki. 1993. Functional erythropoietin receptor of the cells with neural characteristics. Comparison with receptor properties of erythroid cells. I. Biol. Chem. 268: 11208-11216.

McDonald, T.P., M.B. Cottrell, R.E. Clift, W.C. Cullen, and F.K. Lin. 1987. High doses of recombinant erythropoietin stimulate platelet production in mice. Exp. Hematol. 15: 719-721.

Medvinsky, A.L., N.L. Samoylina, A.M. Muller, and E.A. Dzierzak. 1993. An early pre-liver intraembryonic source of CFU-S in the developing mouse. Nature 364: 64-67.

Migliaccio, A.R., G. Migliaccio, A. D'Andrea, M. Baiocchi, S. Crotta, S. Nicolis, S. Ottolenghi, and J.W. Adamson. 1991. Response to erythropoietin in erythroid subclones of the factor-dependent cell line 32D is determined by translocation of the erythropoietin receptor to the cell surface. Proc. Natl. Acad. Sci. 88: 11086-11090. 
Miller, I.J. and J.J. Bieker. 1993. Identification of a novel, erythroid-specific murine transcription factor structurally related to the Krüppel family of nuclear proteins. Mol. Cell. Biol. 13: 2776-2786.

Moore, M.A.S. and D. Metcalf. 1970. Ontogeny of the haemopoietic system: Yolk sac origin of in vivo and in vitro colony forming cells in the developing mouse embryo. Br. $/$. Hematol. 18: 279-296.

Mortensen, R.M., D.A. Conner, S. Chao, L.A.A. Geisterfer, and J.G. Seidman. 1992. Production of homozygous mutant ES cells with a single targeting construct. Mol. Cell. Biol. 12: 2391-2395.

Nijhof, W., P.K. Wierenga, K. Sahr, N. Beru, and E. Goldwasser. 1987. Induction of globin mRNA transcription by erythropoietin in differentiating erythroid precursor cells. Exp. Hematol. 15: 779-784.

Ohneda, O., N. Yanai, and M. Obinata. 1993. Erythropoietin as a mitogen for fetal liver stromal cells which support erythropoiesis. Exp. Cell Res. 208: 327-331.

Papayannopoulou, T., M. Brice, and A. Blau. 1993. Kit ligand in synergy with interleukin-3 amplifies the erythropoietin-independent, globin-synthesizing progeny of normal human burst-forming units-erythroid in suspension cultures: Physiologic implications. Blood 81: 299-310.

Pevny, L., C.S. Lin, V. D'Agati, M.C. Simon, S.H. Orkin, and F. Costantini. 1995. Development of hematopoietic cells lacking transcription factor GATA-1. Development 121: 163712.

Ripoche, M.A. and C.A. Cudennec. 1983. Adult hemoglobins are synthesized in yolk sac microenvironment obtained from murine cultured blastocysts. Cell Differ. 13: 125-131.

Robertson, E., A. Bradley, M. Kuehn, and M. Evans. 1986. Germline transmission of genes introduced into cultured pluripotential cells by retroviral vector. Nature 323: 445-448.

Rovera, G., C. Magarian, and T.W. Borun. 1978. Resolution of hemoglobin subunits by electrophoresis in acid urea polyacrylamide gels containing Triton X-100. Anal. Biochem. 85: $506-518$.

Russell, E.S. 1979. Hereditary anemias of the mouse: A review for geneticists. Adv. Genet. 20: 357-459.

Russell, E.S., M.W. Thompson, and E.C. McFarland. 1968. Anal$y$ sis of effects of $W$ and $f$ genic substitutions on fetal mouse hematology. Genetics 58: 259-270.

Schmitt, R.M., E. Bruyns, and H.R. Snodgrass. 1991. Hematopoietic development of embryonic stem cells in vitro: Cytokine and receptor gene expression. Genes \& Dev. 5: 728-740.

Shivdasani, R.A., E.L. Mayer, and S.H. Orkin. 1995. Absence of blood formation in mice lacking the T-cell leukemia oncoprotein tal-1/SCL. Nature 373: 432-434.

Simon, M.C., L. Pevny, M.V. Wiles, G. Keller, F. Costantini, and S.H. Orkin. 1992. Rescue of erythroid development in gene targeted GATA-1 ${ }^{-}$mouse embryonic stem cells. Nature Genet. 1: 92-98.

Tsai, F.Y., G. Keller, F.C. Kuo, M. Weiss, J. Chen, M. Rosenblatt, F.W. Alt, and S.H. Orkin. 1994. An early haematopoietic defect in mice lacking the transcription factor GATA-2. Nature 371: 221-226.

Tybulewicz, V.L., C.E. Crawford, P.K. Jackson, R.T. Bronson, and R.C. Mulligan. 1991. Neonatal lethality and lymphopenia in mice with a homozygous disruption of the c-abl protooncogene. Cell 65: 1153-1163.

Warren, A.J., W.H. Colledge, M.B.L. Carlton, M.J. Evans, A.J.H. Smith, and T.H. Rabbits. 1994. The oncogenic cysteine-rich LIM domain protein Rbtn2 is essential for erythroid development. Cell 78: 45-57.
Weiss, M.J., G. Keller, and S.H. Orkin. 1994. Novel insights into erythroid development revealed through in vitro differentiation of GATA-1 embryonic stem cells. Genes \& Dev. 8: 1184-1197.

Williams, N., H.M. Jackson, R.R. Eger, and M.W. Long. 1981. The separate roles of factors in murine megakaryocyte colony formation. In Megakaryocytes in vitro: Biology and precursors (ed. B. Evatt, R. Levine, and N. Williams), pp. 59-75. Elsevier Science Publishing Co., New York.

Wong, P.M., B.J. Clarke, D.H. Carr, and D.H. Chui. 1982. Adult hemoglobins are synthesized in erythroid colonies in vitro derived from murine circulating hemopoietic progenitor cells during embryonic development. Proc. Natl. Acad. Sci. 79: 2952-2956.

Wong, P.M.C., S.-W. Chung, S.M. Reicheld, and D.H.K. Chui. 1986. Hemoglobin switching during murine embryonic development: Evidence for two populations of embryonic erythropoietic progenitor cells. Blood 67: 716-721.

Youssoufian, H., L.I. Zon, S.H. Orkin, A.D. D'Andrea, and H.F. Lodish. 1990. Structure and transcription of the mouse erythropoietin receptor gene. Mol. Cell. Biol. 10: 3675-3682.

Youssoufian, H., G. Longmore, D. Neumann, A. Yoshimura, and H.F. Lodish. 1993. Structure, function, and activation of the erythropoietin receptor. Blood 81: 2223-2236. 


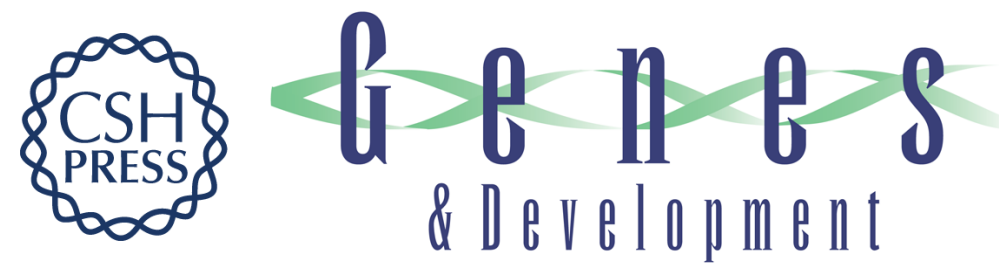

\section{Differential effects of an erythropoietin receptor gene disruption on primitive and definitive erythropoiesis.}

C S Lin, S K Lim, V D'Agati, et al.

Genes Dev. 1996, 10:

Access the most recent version at doi:10.1101/gad.10.2.154

References This article cites 57 articles, 27 of which can be accessed free at: http://genesdev.cshlp.org/content/10/2/154.full.html\#ref-list-1

License

Email Alerting

Service

Receive free email alerts when new articles cite this article - sign up in the box at the top right corner of the article or click here.

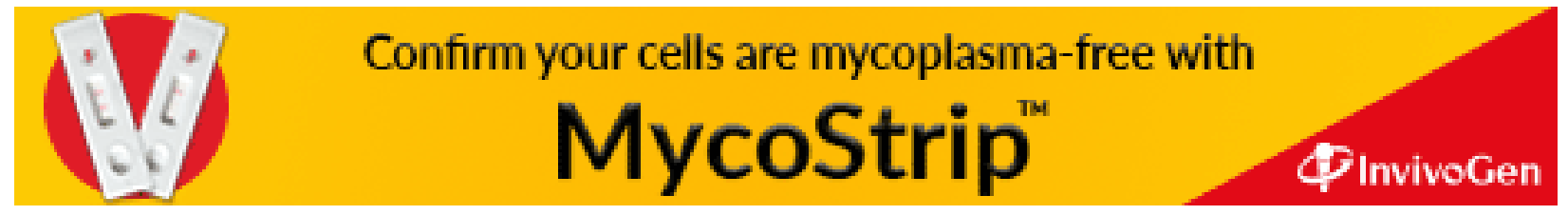

